\title{
Lifestyle, metabolic compensation in patients with type 2 diabetes mellitus and the risk of chronic disease complications
}

\section{ABSTRACT}

Introduction. Poorly-controlled diabetes mellitus leads to organ-related complications of this disease and in order to prevent such complications, change of lifestyle is of essential importance. By correcting metabolic control in patients with type 2 diabetes, it is possible to slow down their progress and prevent their further development. The aim of the study was to evaluate the influence of lifestyle on metabolic control of diabetes mellitus and on chronic complications.

Material and method. The study included a group of 206 patients with type 2 diabetes mellitus aged between 30 and 66 and older, with the duration of the disease up to 5 years. 183 fully completed questionnaires were finally analyzed. In the presented paper, a diagnostic survey was used as a research method, a technique which was an original questionnaire survey developed by the authors and an analysis of medical documentation.

Results. The analysis of this research showed that there are no patients who would meet all the parameters of metabolic compensation. Lifestyle change after diabetes diagnosis was declared by $\mathbf{8 6 . 5 \%}$ of the respondents; however, their confirmation does not reflect the clinical picture of the disease and the dietary habits presented by them. Diabetes complications were observed among respondents and were more common

Address for correspondence:

dr n. o zdrowiu Małgorzata Kołpa

Państwowa Wyższa Szkoła Zawodowa w Tarnowie

ul. Mickiewicza 8, 33-100 Tarnów

e-mail: MalgorzataKolpa@interia.pl

Clinical Diabetology 2018, 7, 3, 151-158

DOI: $10.5603 /$ DK.2018.0011

Received: 18.11.2017

Accepted: 05.03.2018 among the women (55.8\%). Neuropathy was the most common of these complications.

Conclusions. The respondents' knowledge about the disease is not used in practice and does not translate into their lifestyle. The level of diabetes control among the population under examination does not significantly depend on their occupational activity, but shows slight dependence on their health behaviors. Lack of metabolic control of diabetes mellitus results in subsequent complications. (Clin Diabetol 2018; 7, 3: 151-158)

Key words: diabetes mellitus, chronic complications, metabolic compensation

\section{Introduction}

Type 2 diabetes mellitus has become a growing epidemic for a good reason. The number of people falling ill with, as well as the complications of, this disease can be observed growing steadily, which is a serious health and social problem. An increased incidence of the disease can be seen mainly in developing and highly industrialized countries, which is associated with an inappropriate lifestyle, obesity, insufficient physical activity or ageing populations [1-3].

It was in 2015 that the International Diabetes Federation (IDF) published statistical data, showing that 415 million people are already affected worldwide, including 59.8 million in Europe. It is estimated that by 2040 the number of individuals with diabetes will have increased to 642 million, thus implying that one person in 10 will have diabetes [4].

People suffering from the disease are mostly people of working age, and they constitute about $77 \%$ of patients. The disease is more likely to be diagnosed in 
men than in women, although the difference is decreasing [2]. Currently, 2.3 million people are affected in Poland, with the incidence estimated at $7.6 \%$ [3]. For type 2 diabetes mellitus, the exact number of patients is difficult to estimate. More than a third of people do not know about the disease, which is associated with its latent course, as most often it is diagnosed only after a few years $[3,5]$.

It is difficult to estimate the exact mortality rate for diabetes mellitus as the disease is not considered to be the leading cause in the death record [3]. According to IDF, in 2015 the number of deaths in the world was 5 million, with 21.5 thousand deaths due to this disease in Poland alone. It is believed that owing to poorly balanced or even untreated diabetes, leading to numerous micro- and microvascular complications, up to $60-67 \%$ of people - according to various sources $[3,4]-$ die from the disease.

The World Health Organization (WHO) defines diabetes as a set of metabolic disorders characterized by hyperglycaemia resulting from a defect in insulin secretion and/or function. Chronic hyperglycaemia is associated with a damage, dysfunction and failure of various organs, especially eyes, kidneys, nerves, heart and blood vessels [6].

There is a conviction among many people that diabetes mellitus is the leading cause of blindness, kidney damage, and limb amputation. Poorly-controlled diabetes mellitus is a progressive disease that can lead to disability and, consequently, even to premature death. It is well-known that a significant role in delaying diabetic complications is played by lifestyle modification, especially nutrition, body mass normalization or regular motor activity, which is essential for the proper functioning of the patient $[7,8]$.

A cause for concern is that the age at which type 2 diabetes mellitus is diagnosed is also decreasing, thus including children and adolescents. Apart from environmental factors, the disease can also be caused by puberty period, low birth weight or polycystic ovary syndrome $[5,9]$.

The key issue in preventing organ complications of the disease is the pursuit of metabolic compensation, i.e. reaching target values for many parameters in accordance with the guidelines set by the Polish Diabetes Association (PTD) [10]. Achieving adequate metabolic compensation in diabetic patients with established systemic complications may slow down their progression as well as inhibiting further development of morbidity [8].

In the elderly, often with other co-morbidities, compensation criteria should be lowered to the extent that at least a good quality of life is maintained and hyperglycaemia does not negatively affect a patient's well-being. Type 2 diabetes mellitus is a progressive disease, therefore continuous monitoring and intensive treatment are necessary in order to maintain adequate metabolic compensation [11, 12]. It is estimated that about two thirds of patients do not meet the therapeutic objectives recommended by the PTD [13]. In addition, achieving adequate metabolic compensation, as recommended, is only possible if a patient follows the recommendations and is aware of how their lifestyle affects the level of glycaemia, lipids, or arterial pressure.

The aim of the study was to evaluate the influence of lifestyle on metabolic control and chronic complications of type 2 diabetes mellitus.

\section{Methods}

The pilot study included 206 patients with type 2 diabetes mellitus aged between 30 years of age and 66 years and over, with the duration of the disease up to 5 years. 183 completed questionnaires were finally analysed. Among the respondents there were $51.9 \%$ women and $48.1 \%$ men. Patients with gestational diabetes, patients with type 1 diabetes mellitus and those with type 2 diabetes suffering from the disease for over 5 years were excluded from the study.

The research was conducted from October 2016 to January 2017 in one of the diabetic clinics for adults in Tarnów. The participants in the study as well as the head of the counselling centre gave their consent. They were also informed about the advisability of the research. Their anonymity was also ensured.

As a research method, a diagnostic survey was used with the help of a technique which was an original questionnaire survey developed by the authors and an analysis of medical documentation. The questionnaire was created for the purposes of the study and consisted of 35 questions. The author's questionnaire included metric questions and targeted questions on the disease and lifestyle. The questionnaire contained closed questions on the basis of which the subjective feelings of the respondents could be assessed.

The medical records provided information on the results of laboratory tests of $\mathrm{HBA}_{1 c^{\prime}}$ eGFR, creatinine, total cholesterol, LDL, HDL, TG, fasting glycaemia, glycaemia measured 2 hours after meal as well as of blood pressure. Fasting and 2-hour post meal glucose concentration was measured in capillary blood with Glukometr OneTouch Select ${ }^{\circledR}$ Plus company LifeScan Inc.

The collected material was subjected to statistical analysis. The differences between variables were verified with the use of the $\chi^{2}$ independence test, assuming significance level $p<0.05$. Calculations were made with the SPSS program. 


\section{Results}

$4.9 \%$ of the respondents presented with diabetes for 6 months. $15.3 \%$ of the respondents presented with diabetes for 7 to 12 -months, whereas the majority of the respondents presented with diabetes for 2 to 4 years $(44.3 \%)$ or 5 years $(35.5 \%)$.

The respondents assessed their knowledge of diabetes as being good (44.3\%) or average (43.7). More than half of the respondents (61.7\%) did not remember the result of the last lipidogram measurement and the value of glycated haemoglobin (66.7\%).

On having the disease diagnosed, more than half of the respondents declared a change in lifestyle through self-control $(86.5 \%)$, regular visits to a diabetologist $(76.3 \%)$ or proper nutrition $(73.7 \%)$. Most of the respondents $(83.1 \%)$ used a diet as a result of diabetes; nevertheless, the level of adherence to the medical recommendations was slightly above the average level (3.21 points on a scale of 1-5 points). The regularity of eating meals was indicated by $56.3 \%$ of the people, in most cases those consuming 3-4 meals a day $-71.6 \%$. Only $18.0 \%$ declared not snacking on between meals. Those who did eat between meals usually consumed fresh fruit and vegetables (45.3\%), but not much fewer sweets (38.7\%). When evaluating the frequency of consumption of selected products, a 1-5 point scale was applied, where the higher scores corresponded to a lower frequency of reaching for a given product. It was found that most patients used tea/coffee (1.22), fruits/vegetables (1.65) and margarine/butter/lard/vegetable oils (1.80). They consumed less meat and fewer meat products (2.16), less milk and fewer milk products (2.35), rice, various types of groats (2.79), flour products, pasta, dumplings (2.80). The least often they ate fish (3.07), sweets, cakes (3.09), sweetened drinks (3.87) or fast food (4.53).

From among the stimulants and mild drugs, the respondents most often used coffee $(82.5 \%)$, and almost half of them $(48.6 \%)$ would sweeten tea or coffee. It is equally important to note that despite the declared good knowledge about their disease, 56.8\% of the respondents did not know the impact of alcohol consumption on blood sugar levels. $14.8 \%$ of the respondents claimed that their alcohol consumption had no impact on their level of glycaemia at all. Although the majority of the respondents $(83.1 \%)$ considered regular physical activity an important component of diabetes treatment, more than half of them (61.7\%) chose the car as a convenient means of transportation. The respondents most often spent time passively in watching TV/listening to the radio (65.6\%) - the results did not add up to $100 \%$, because the respondents could indicate more than one answer.
Most of the respondents were often or sometimes exposed to stressful situations (79.2\%), dealing with them most often by talking to their relatives (34.4\%), reaching for sedatives $(26.2 \%)$ or taking a walk (24, $0 \%)$. Slightly more than half of the respondents $(55.7 \%)$ spent $7-8$ hours a day sleeping, with only $42.1 \%$ of them not reporting problems with insomnia.

The level of glycaemic control in diabetic patients was estimated on the basis of 12 parameters $\left(\mathrm{HbA}_{1 \mathrm{c}^{\prime}}\right.$ creatinine, eGFR, total cholesterol, TG, LDL, HDL, systolic blood pressure, diastolic blood pressure, fasting and postprandial glucose, BMI). 1 point was allocated for having a given parameter of the standard value, and 0 points for deviations from the standard. The total number of points could be within a range $0-12$ points. The results obtained were transformed to a scale of $0-100 \%$, where higher scores corresponded to better metabolic control level in diabetes mellitus. It was found that the average level of glycaemic control in diabetic patients was $50.05 \%(S D=14.29)$ and ranged from $16.67 \%$ to $83.33 \%$. The results obtained indicated that there were no fully glycaemically balanced patients in the study group. The results were divided into 2 groups, assuming that the glycaemic control was indicated by a result above $50 \%$, which was adequate to obtain standard results from at least 7 out of the 11 parameters.

It was demonstrated that in the case of $60.1 \%$ of the respondents their diabetes mellitus was not managed properly. In $39.9 \%$ of the respondents partial metabolic compensation of diabetes was reported (Tab. 1).

The glycaemic control in diabetes was significantly more common among the respondents who were on a diet due to the disease $(90.4 \%)(p=0.0308)$. Changes in lifestyle and systematic self blood glucose measurements were not observed to be significantly related to metabolic control in diabetes (Tab. 2).

Those with compensated diabetes mellitus were found to more frequently drink two or more cups of coffee a day (31.5\%). The respondents with non-compensated diabetes mellitus more often drank one cup of coffee per day $(56,4 \%)$. The differences found were statistically significant $(p=0.0207)$. However, smoking and alcohol consumption were not found to significantly affect diabetes metabolic control among the studied patients (Tab. 3).

Glycaemic control was not shown to be significantly associated with the time spent on physical activity as well as on the typically used means of transport; nor was it affected by stressful situations and sleep problems of the patients under examination.

Among the respondents with complications, 55.8\% were women and $44.2 \%$ men. The complications were 
Table 1. Level of diabetes compensation in the study group

\begin{tabular}{|c|c|c|}
\hline & $\mathbf{N}$ & $\%$ \\
\hline \multicolumn{3}{|l|}{$\mathrm{HbA}_{1 \mathrm{c}}$} \\
\hline Above standard & 82 & $44.8 \%$ \\
\hline Standard & 101 & $55.2 \%$ \\
\hline \multicolumn{3}{|l|}{ eGFR } \\
\hline Below standard & 17 & $9.3 \%$ \\
\hline Standard & 166 & $90.7 \%$ \\
\hline \multicolumn{3}{|l|}{ Creatinine } \\
\hline Beyond standard & 13 & $7.1 \%$ \\
\hline Standard & 170 & $92.9 \%$ \\
\hline \multicolumn{3}{|l|}{ Total cholesterol } \\
\hline Above standard & 111 & $60.7 \%$ \\
\hline Standard & 72 & $39.3 \%$ \\
\hline \multicolumn{3}{|l|}{ LDL } \\
\hline Above standard & 145 & $79.2 \%$ \\
\hline Standard & 38 & $20.8 \%$ \\
\hline \multicolumn{3}{|l|}{ HDL } \\
\hline Below standard & 49 & $26.8 \%$ \\
\hline Standard & 134 & $73.2 \%$ \\
\hline \multicolumn{3}{|l|}{ TG } \\
\hline Above standard & 85 & $46.4 \%$ \\
\hline Standard & 98 & $98 \%$ \\
\hline \multicolumn{3}{|c|}{ Systolic blood pressure } \\
\hline Above standard & 117 & $63.9 \%$ \\
\hline Standard & 66 & $36.1 \%$ \\
\hline \multicolumn{3}{|c|}{ Diastolic blood pressure } \\
\hline Above standard & 15 & $8.2 \%$ \\
\hline Standard & 168 & $91.8 \%$ \\
\hline \multicolumn{3}{|l|}{ Fasting glucose } \\
\hline Beyond standard & 173 & $94.5 \%$ \\
\hline Standard & 10 & $5.5 \%$ \\
\hline \multicolumn{3}{|l|}{ Postprandial glucose } \\
\hline Above standard & 119 & $65.0 \%$ \\
\hline Standard & 64 & $35.0 \%$ \\
\hline
\end{tabular}

slightly more frequent among people aged 66 and over (34.9\%). To a lesser extent, they occurred in people aged $61-65$ (18.6\%) or 51-60 (25.6\%). The incidence of diabetes was not significantly associated with other diseases in the subjects. It was shown, however, that the people treated for hypertension were also more likely to develop diabetes complications. Among those without diabetes complications, $20.7 \%$ were patients without arterial hypertension. The differences found were not statistically significant.

Among the patients with diabetic complications, $20.9 \%$ with diabetes mellitus presented good glycaemic control. In the group of patients without diabetes complications, the percentage was significantly higher $(45.7 \%)$. The differences found were statistically significant ( $p=0.0037$ ) (Tab. 4).

Patients without diabetes complications (50.0\%) were more often exposed to stress than those with complications who occasionally faced stressful situations (39.5\%). People with complications were more likely to sleep 7-8 hours (65.1\%), and those without complications more often 4-6 hours $(37.1 \%)$ a day. It was demonstrated that it were people without complications that more often had no problems with insomnia (42.9\%) than those with diabetes complications (39.5\%). The occurrence of drowsiness was not related to diabetes mellitus complications. The differences observed were not statistically significant.

Diabetic complications were observed in $23.5 \%$ of the patients examined. The most common complications included neuropathy $(12.0 \%)$, less frequently retinopathy $(7.7 \%)$, very infrequently nephropathy (3.8\%) or diabetic foot $(1.1 \%)$.

It was observed that patients with retinopathy less frequently $(45.5 \%)$ had systematic follow-up visits to a diabetes clinic than those without retinopathy (78.6\%)

Table 2. Glycaemic control in diabetes mellitus

\begin{tabular}{|c|c|c|c|c|c|}
\hline & \multicolumn{4}{|c|}{ Glycaemic control in diabetes } & \multirow[t]{3}{*}{$\mathbf{P}$} \\
\hline & \multicolumn{2}{|c|}{ No } & \multicolumn{2}{|c|}{ Yes } & \\
\hline & $\mathbf{N}$ & $\%$ & $\mathbf{N}$ & $\%$ & \\
\hline \multicolumn{6}{|l|}{ Change of life style } \\
\hline Yes & 94 & $85.5 \%$ & 62 & $84.9 \%$ & 0.9222 \\
\hline No & 16 & $14.5 \%$ & 11 & $15.1 \%$ & \\
\hline \multicolumn{6}{|c|}{ Systematic blood glucose measurements with a glucometer } \\
\hline Yes & 82 & $74.5 \%$ & 52 & $71.2 \%$ & 0.6202 \\
\hline No & 28 & $25.5 \%$ & 21 & $28.8 \%$ & \\
\hline \multicolumn{6}{|c|}{ Being on a diet due to the disease } \\
\hline Yes & 86 & $78.2 \%$ & 66 & $90.4 \%$ & 0.0308 \\
\hline I am not on a diet & 24 & $21.8 \%$ & 7 & $9.6 \%$ & \\
\hline
\end{tabular}


Table 3. Glycaemic control in diabetes mellitus and use of drugs/stimulants in the study group of patients

\begin{tabular}{|c|c|c|c|c|c|}
\hline & \multicolumn{4}{|c|}{ Glycaemic control in diabetes mellitus } & \multirow[t]{3}{*}{$\mathbf{P}$} \\
\hline & \multicolumn{2}{|c|}{ No } & \multicolumn{2}{|c|}{ Yes } & \\
\hline & $\mathbf{N}$ & $\%$ & $\mathbf{N}$ & $\%$ & \\
\hline \multicolumn{6}{|l|}{ Coffee consumption } \\
\hline Yes - once a day & 62 & $56.4 \%$ & 26 & $35.6 \%$ & 0.0207 \\
\hline Yes - occasionally & 14 & $12.7 \%$ & 9 & $12.3 \%$ & \\
\hline Yes -2 or more cups a day & 17 & $15.5 \%$ & 23 & $31.5 \%$ & \\
\hline I do not drink coffee & 17 & $15.5 \%$ & 15 & $20.5 \%$ & \\
\hline \multicolumn{6}{|l|}{ Cigarette smoking } \\
\hline Yes - every day & 24 & $21.8 \%$ & 19 & $26.0 \%$ & 0.2568 \\
\hline Yes - occasionally & 3 & $2.7 \%$ & 6 & $8.2 \%$ & \\
\hline I do not smoke & 54 & $49.1 \%$ & 34 & $46.6 \%$ & \\
\hline I used to smoke in the past & 29 & $26.4 \%$ & 14 & $19.2 \%$ & \\
\hline \multicolumn{6}{|l|}{ Alcohol consumption } \\
\hline Yes - every day & 0 & $0.0 \%$ & 0 & $0.0 \%$ & 0.5757 \\
\hline Yes - a few times a week & 6 & $5.5 \%$ & 3 & $4.1 \%$ & \\
\hline Yes - once a week & 7 & $6.4 \%$ & 3 & $4.1 \%$ & \\
\hline A few times a month & 5 & $4.5 \%$ & 3 & $4.1 \%$ & \\
\hline Occasionally & 57 & $51.8 \%$ & 32 & $43.8 \%$ & \\
\hline I do not drink alcohol & 35 & $31.8 \%$ & 32 & $43.8 \%$ & \\
\hline
\end{tabular}

Table 4. The incidence of diabetes complications and glycaemic control in diabetes mellitus

\begin{tabular}{lccccc}
\hline Glycaemic control & \multicolumn{4}{c}{ Complications } & \multirow{2}{*}{ p } \\
\cline { 2 - 5 } in diabetes mellitus & \multicolumn{2}{c}{ Yes } & \multicolumn{2}{c}{ No } & \\
\cline { 2 - 5 } & $\mathbf{N}$ & $\%$ & $\mathbf{N}$ & $\%$ & \\
\hline No & 34 & $79.1 \%$ & 76 & $54.3 \%$ & 0.0037 \\
Yes & 9 & $20.9 \%$ & 64 & $45.7 \%$ & \\
\hline
\end{tabular}

( $p=0.0127)$. It was also demonstrated that all the patients with retinopathy had a 2 hours postprandial glucose level above normal $(p=0.0025)$. Among those without retinopathy, this percentage was $62.1 \%$. Slight differences also indicated that patients with retinopathy were more likely to have $\mathrm{HbA}_{1 \mathrm{c}}$ value above the normal range (71.4\%).

Normal TG values were significantly more frequent ( $p=0.0293$ ) among patients without neuropathy (56.5\%) than for patients with neuropathy (31.8\%).

It was found that the patients with nephropathy significantly more frequently $(p=0.0186)$ had eGFR below the normal range (42.9\%), extra-standard creatinine $(57.1 \%)(p=0.0005)$, and, less frequently, LDL above the norm (28.6\%). Slight differences suggest that total cholesterol within the normal range is more common in people with nephropathy rather than in those without this complication.
The incidence of insomnia problems did not significantly differentiate glycaemic control of diabetes mellitus. Slight differences suggested that people with insomnia problems were more likely to have diastolic blood pressure levels above the normal range (14.3\%).

It was observed that all the patients with moderate sleepiness and severe drowsiness had fasting glycaemia outside the normal range ( $p=0.0096)$. Fasting glycaemia within the normal range was more frequently found in patients with normal sleepiness level (3.5\%) or mild drowsiness level (19.2\%). Slight differences also suggested that people with normal sleepiness and moderate drowsiness were more likely to have TG in the normal range when compared to those with mild sleepiness or severe drowsiness.

\section{Discussion}

Changing lifestyle from unhealthy to pro-healthy is considered to be an integral part of diabetes treatment. Such a change is conducive to compensation of diabetes mellitus, which results in blood glucose concentration levels as close as possible to normal values, achieving optimal values of serum lipids, regulating blood pressure, and reducing weight in overweight and obese individuals.

The results of the study show that in the study population there were no patients fully meeting all the criteria of the proper glycaemic control of diabetes. 
This is confirmed by reports from Kazanowska-Bystryk et al., which show that a small percentage of patients with diabetes mellitus achieve good metabolic control [11]. This may be explained by a gradual increase in the number of diabetic patients, which makes it impossible to provide proper medical care, which undoubtedly hinders the PTD objectives. On the other hand, Steno-2 and PROSIT studies have shown that if a patient undergoes multidirectional therapy that takes all therapeutic goals into consideration rather than focus on glycaemia control alone, it is possible to achieve these intended goals $[14,15]$. No less important is the involvement of a patient and their family in the treatment process. An additional supplement to the success treatment is a patient's knowledge of the disease, nutrition, selfmonitoring as well as self-control, and the awareness of the need to change their lifestyle. Unfortunately, our own research shows a discrepancy between the respondents' declared knowledge and their lifestyle. A significant percentage of the respondents (83.1\%) participating in the study declared that they would follow the recommended diet after having the disease diagnosed. A deeper analysis of the statements made by the respondents suggests that they understood the term diet in various ways. Similar results were found in multi-centre studies conducted by Klupa et al. [16] where $55.9 \%$ of the respondents in study declared observance of dietary principles recommended in diabetes mellitus. However, answers to more detailed questions showed a considerable lack of knowledge about the diet. Also, inconsistency in their statements was observed when analyzing the number of meals consumed by the patients during the day. In the interview, the respondents would repeatedly state that they could not imagine a day without consuming meat or flour products, and would not deny that white flour was the basis of their diet. Therefore, given their frequency of consumption several times a week, it is meat products, closely followed by flour products, that are in the lead. Diabetics should replace these products with fish, which, in fact, were rarely consumed by them - only a few times a month. Similar results were reported by Szewczyk et al. [17], who evaluated the diet of diabetics and who found that their studied group of patients would eat fish as infrequently, meat products being selected significantly more often. It can be assumed that low incomes may constitute a barrier to composing an appropriate diet, often forcing the patient to buy cheaper and less healthy products.

The analysis of the results of our own research into the nutritional status of the patients under examination showed that their dietary errors did not differ from those described by Bulzacka et al. [18]. The majority of the respondents of these studies would consume the recommended number of meals 4-5 times a day, but they would do it irregularly (Bulzacka et al. - over 50\%) [18]. Mędrela-Kuder [19] reports that $71 \%$ of the diabetics surveyed consumed 4-5 meals a day, but only $48 \%$ of them would do it regularly. Similar findings were obtained by Górska-Ciebiada et al. [20] in their research, where the respondents ate the recommended number of meals daily, but irregularly. Our own research confirms the above-mentioned reports in terms of the declaration of meal consumption at fixed times ( $56.3 \%$ of the respondents). At the same time, it should be noted that only slightly fewer respondents $(43.7 \%)$ admitted not eating regularly, which results in high postprandial glycaemia among surveyed patients.

The distribution of food products throughout the day should be selected in such a way that it can match the ordered treatment. As for the amount of food consumed per day, the results obtained from our own research did not coincide with the results of the authors mentioned above, because here the vast majority of diabetics consumed 3-4 meals per day, which, unfortunately, affects the unsatisfactory results of glucose levels during the day.

Other nutritional errors observed in the study group involved snacking between meals (54.6\%), improper preparation of meals and sweetening of coffee or tea, or salting meals. The respondents selected fruit and vegetables $(45.3 \%)$ and also sweets (38.7\%) as their snacks. Our own results are similar to those presented by Górska-Ciebieda et al. [20], where $47.5 \%$ of the respondents with diabetes mellitus snack between meals, mostly fruits and vegetables.

Although the vast majority of the respondents declared proper nutrition habits $(73.7 \%)$, and as a way of preparing meals, they indicated boiling $(72.7 \%)$ and stewing $(44.8 \%)$, the percentage of the respondents who preferred frying was not small (32.2\%). Similar results were reported by Król et al. [21]. Slightly worse results were presented by Bulzacka et al. [18], and by Mędrela-Kuder [19]. In these studies, patients were mostly in favour of frying and baking ( $40 \%$ of the respondents).

Reducing sodium intake and ensuring an adequate supply of potassium, calcium and magnesium all play an important role in the prevention of diabetes and its complications. Similarly to studies performed by other authors [19-21] our own research led us to the assertion that the respondents' diet contained too much sodium. The results presented in this paper showed that $44.3 \%$ of the respondents put extra salt in their dishes. The percentage of the respondents who put extra salt in their dishes in our own research was slightly higher than that in the studies by Mędrela-Kuder (35\%) [19] 
and Górska-Ciebiada et al. (29.5\%) [20]. The use of more salt can cause water retention in the body and can also lead to hypertension, so consumption of salt should be restricted to all diabetics. Based on the results obtained by our own research and by the research done by Górska-Ciebieda et al. [20], the coexistence of the above disease was confirmed by the vast majority of respondents.

Excess sugar leads to an increase in glycaemia, thereby contributing to the destabilization of diabetes. Small quantities of sugar can be replaced by sweeteners in portions recommended by the manufacturers, which are also recommended by the PTD, bearing in mind that the substitute substance is not fructose [10]. In our own study, it was found that the respondents used sugar in a slightly higher percentage than the patients in the Król et al. study [21]. In the analysis of the research results of Górska-Ciebiada et al. [20], it was found that few respondents $(33.6 \%)$ declared using such substitutes as sweeteners.

Rachmani et al. [22] in their several years' observation of 165 patients with both type 2 diabetes mellitus and hypertension demonstrated that better metabolic compensation and reduction of mortality were associated with both systematic and extended education. Each patient, regardless of the form of insulin therapy or drug treatment, is entitled to the same level of education by an equally qualified therapeutic team. Similarly, the DIGAMI-2 study proven that, regardless of the type of treatment undertaken, an important role is played by glycaemic compensation, which is undoubtedly influenced by education [15].

According to our own research, although the majority of the respondents $(83.1 \%)$ had knowledge of the beneficial impact of regular physical activity on the health of diabetics, more than half of the respondents (65.6\%) preferred passive leisure. The most popular form of spending time was watching TV/listening to the radio. Some of the respondents spent time in the garden or on a plot of land, as well as doing the housework and walking; the respondents, however, spent only 10-30 minutes a day on these activities. Similar results were reported by Mędrela-Kuder [23] and Bulzacka et al. [18], confirming the low percentage of patients who performed any physical activity. Król et al. [21] reported that more than $41 \%$ of the respondents with diabetes, mostly men $(22.22 \%)$, spend more than 30 minutes a day on physical activity. However, fewer than $27 \%$ exercise less than 30 minutes a day, and $22 \%$ confirmed a lack of physical activity. Klupa et al. [16] indicate that only $57.4 \%$ of the patients under examination reported any form of intentional physical activity in their spare time.
In our own studies, the respondents were more likely to drink coffee $(82.5 \%)$ than alcohol, which was occasionally consumed by $48.6 \%$ of respondents. Diabetics should avoid alcohol, as alcohol can lead to hypoglycaemia, thereby directly putting their lives in jeopardy. Similar results were reported in the paper by Mędrela-Kuder [19], where occasional alcohol consumption was declared by $41 \%$ of the respondents. In turn, Król et al. [21] and Gacek [24] reported low alcohol consumption in their study group.

The majority of patients in our study experienced sleep disorders; still, as is well known, it is the appropriate length of sleep that improves the well-being and mental comfort of each individual. When examining the length of sleep among the respondents whose answers are presented in this paper, it can be noticed that more than half $(55.7 \%)$ declared that they sleep 7-8 hours per day, which is the recommended time. Similar findings were obtained by Król et al. [21], where more than $49 \%$ of diabetics declared 8 hours of sleep.

A consequence of improper glycaemic control in diabetes are late complications, therefore emphasis should be laid upon developing correct behaviours conducive to better health. Our own research shows that diabetic neuropathy was the most common complication, followed by retinopathy. The results obtained by both Duczak et al [1], Kowalczyk et al. [25], and Król et al. [21], demonstrated that retinopathy and diabetic foot syndrome were more common than neuropathy.

Taking into account the whole study group, whose results are presented, $23.5 \%$ of the respondents reported complications, $12.0 \%$ of which being neuropathy. It is to be assumed, though, that the number of neuropathic patients constitutes a higher percentage, due to there being undiagnosed patients with regard to this complication. The reason for this is that neuropathy tests are rarely done and only if a person with diabetes reports ailments that indicate these complications. The patient's ignorance is most often due to their lack of knowledge, laconic self-observation or self-care, for which diabetic patients are not really prepared.

Analysing the results of the study, the association of retinopathy with elevated blood pressure was shown to have a higher incidence of diabetic complications, including retinopathy, in those treated for hypertension. The relationship between retinopathy and hypertension is also illustrated by Fowler [26].

In the present study, imperfections can be noticed manifested by doubts as to the adequacy of the results obtained, which are dictated by inaccuracies in the declaration of the patients under examination and their actual way of being. Undoubtedly, the presence of an interviewer during the questionnaire session would 
help to fill it in a reliable way, correcting erroneous information which could have been the result of a lack of clear understanding of the question due to, for example, the low educational level of a person under survey, their age or even inability to focus in the course of the survey. Although such a method is not possible in such a large group, it can be inferred that repeating the questionnaire after a period of time would increase the reliability of the results.

\section{Conclusions}

1. Knowledge about diabetes is not used in practice and does not translate into the lifestyle of diabetics, which is unhealthy.

2. The level of glycaemic control among the respondents is low and depends to a small extent on their health behaviours. The lack of proper glycaemic control in diabetes mellitus results in occurrence of diabetes complications among the patients.

3. Glycaemic control in diabetes mellitus does not significantly depend on the occupational activity of the individuals under examination.

\section{REFERENCES}

1. Duczak A, Jankowska-Polańska B. Styl życia pacjentów z cukrzycą typu 2. Współcz Pielęg Ochr Zdr. 2013; 2(3): 50-54.

2. Janeczko D. Epidemiologia cukrzycy typu 2. In: Cukrzyca T.1. Sieradzki J (ed). Via Medica, Gdańsk 2015: 124-142.

3. Piątkiewicz P. Cukrzyca. Aspekty prawne i społeczne. Via Medica, Gdańsk 2016.

4. International Diabetes Federation. Diabetes Atlas 7th edition. IDF, Bruksela 2015.

5. World Health Organization: Definition, diagnosis and classification of diabetes mellitus and its complications. Raport of a WHO Consultation. Part 1. Diagnosis and classification of diabetes mellitus. Geneva, 1999.

6. Tatoń J, Czech A, Bernas M. Otyłość, Zespół metaboliczny. PZWL, Warszawa 2007.

7. Molsa M, Tłuczykont M, Markowicz A, et al. Przestrzeganie zaleceń lekarskich (compliance) u chorych na cukrzycę leczonych w opiece ambulatoryjne. Diabetol Klin. 2012; 1(6): 213-218.

8. Rottermund J, Knapik A, Saulicz M, et al. Determinanty samooceny zdrowia osób chorujących na cukrzycę typu II. Rehabil Med. 2013; 17(4): 5-10.

9. Małecki M, Skupień J. Problemy diagnostyki różnicowej typów cukrzycy. Pol Arch Med Wewn. 2008; 118(7-8): 435-440.
10. Polskie Towarzystwo Diabetologiczne. Zalecenia kliniczne dotyczące postępowania u chorych na cukrzycę 2017. Diabetol Prakt. 2017; 3(supl. A).

11. Kazanowska-Bystryk I, Goryńska A, Solski J. Ocena wyrównania metabolicznego u chorych na cukrzycę typu 2. Wiad Lek. 2011; 64(3): 170-175

12. Sieradzki J. Duże badania kliniczne I wytyczne postepowania. Kryteria wyrównania cukrzycy. In: Cukrzyca T.1. Sieradzki J (ed). Via Medica, Gdańsk 2015: 295-305.

13. Sieradzki J, Koblik T, Nazar M. Próba oceny postępów w leczeniu chorych na cukrzycę typu 2 na podstawie badań przesiewowych $\mathrm{HbA}_{1 c}$ wykonanych w latach 2002 i 2005. Diabetol Prakt. 2008; 9(3-4): 132-139.

14. Colwell JA. In: Cukrzyca nowe ujęcie diagnostyki i leczenia. Tatoń J, Czech A (ed). Urban \& Partner, Wrocław 2004.

15. Czupryniak L, Strojek K. Diabetologia 2016. Via Medica, Gdańsk 2016.

16. Klupa T, Możdżan M, Kokoszka-Paszkot J, et al. Diet-Related Knowledge and Physical Activity in a Large Cohort of InsulinTreated Type 2 Diabetes Patients: PROGENS ARENA Study. Int J Endocrinol. 2016; 2016: 2354956, doi: 10.1155/2016/2354956, indexed in Pubmed: 27703476.

17. Szewczyk A, Białek A, Kukielczak A, et al. Ocena sposobu żywienia osób chorujących na cukrzycę typu 1 i 2. Probl Hig Epidemiologii. 2011; 92(2): 267-271.

18. Bulzacka M, Mikulska A. Styl życia chorych na cukrzyce typu 2 w wieku 50-55 lat a zapotrzebowanie na edukacje zdrowotną. Ann Univ Mariae Curie-Skłodowska. 2007; LXII(Suppl. XVIII): 306-316.

19. Mędrela-Kuder E. Prawidłowa dieta w cukrzycy typu II jako forma rehabilitacji chorych. Rocz Państ Zakł Hig. 2011; 62(2): 219-223.

20. Górska-Ciebiada M, Saryusz-Wolska M, Ciebiada M, et al. Zwyczaje żywieniowe u starszych chorych na cukrzycę. Geriatria. 2015; 9: 7-14.

21. Król H, Zboina B, Nowak-Starz G, et al. Styl życia osób z rozpoznaną cukrzycą typu 2. Zdrowie Dobrostan. 2013; 4: 149-156.

22. Rachmani R, Slavacheski I, Berla M, et al. Treatment of high-risk patients with diabetes: motivation and teaching intervention: a randomized, prospective 8-year follow-up study. J Am Soc Nephrol. 2005; 16 Suppl 1: S22-S26, doi: 10.1681/asn.2004110965, indexed in Pubmed: 15938028.

23. Mędrela-Kuder E. Aktywność fizyczna jako dodatkowa forma rehabilitacji chorych na cukrzycę typu 2. Rocz Państ Zakł Hig. 2010; 61(1): 87-90.

24. Gacek M. Wybrane parametry somatyczne, stan zdrowia i zachowania żywieniowe w grupie chorych na cukrzycę typu 2. Endokrynol Otyłość. 2011; 7(3): 172-173.

25. Kowalczyk D, Czabak O, Wilczewska M, et al. Czy zaburzenia snu i senność w ciągu dnia wpływają na wyrównanie metaboliczne cukrzycy? Badanie z zastosowaniem wybranych narzędzi diagnostycznych, Fam Med Primary Care Rev. 2013; 15(2): 127-128.

26. Fowler MJ. Mikro- i makronaczyniowe powikłania cukrzycy. Diabetol Dypl. 2011; 8(4): 40-44. 